\title{
Coverage of below elbow amputation stump with a soft-tissue periosteal flap
}

Sir,

Avulsion amputation of an extremity is fortunately rare but a devastating injury. Direct injury to the soft tissues and injury to the tiny perforating vessels supplying skin makes reattachment or procuring usable composite flaps from these avulsed and amputated parts difficult. ${ }^{[1]}$ Preserving the function of critical joints and useful length of the stump by providing adequate soft-tissue cover is critical for early rehabilitation and long-term patient comfort.

A young patient presented to us with amputation of hand and degloving of the skin from the upper arm. Replantation was not possible due to the extent of injury and contamination. After sequential debridements, a 'soft tissue periosteal flap' was used for coverage of the below elbow stump. Periosteal flaps from the radius and ulna were raised based on the interosseous membrane. Both bone ends were trimmed and smoothened at the proposed below elbow amputation length, and the flap was used for cover as shown in Figure 1. The flap was composed of the interosseous membrane, with branches of interosseous vessels, the filleted periosteum of radius and ulna [Figures 1 and 2a, b]. Advantages of this proposed local flap were supple tissue with robust circulation, lesser bulk and its maximum availability at the business end so that no flap was lost in transit [Figure $2 \mathrm{~b}$ ]. The stump was later covered with a skin graft and healed well [Figure 2c and d]. Patient has returned to work with alteration of his job profile.

Conventional options for coverage in such defects were either a free flap or distant pedicle flap. Timing of microvascular coverage was a concern as it would have involved anastomosis within the zone of injury. The failure rate in such instances ( $5^{\text {th }}$ day to 3 weeks) is reported to be higher. ${ }^{[2,3]}$ Pedicled flaps from groin or abdomen had potential disadvantages such as: 


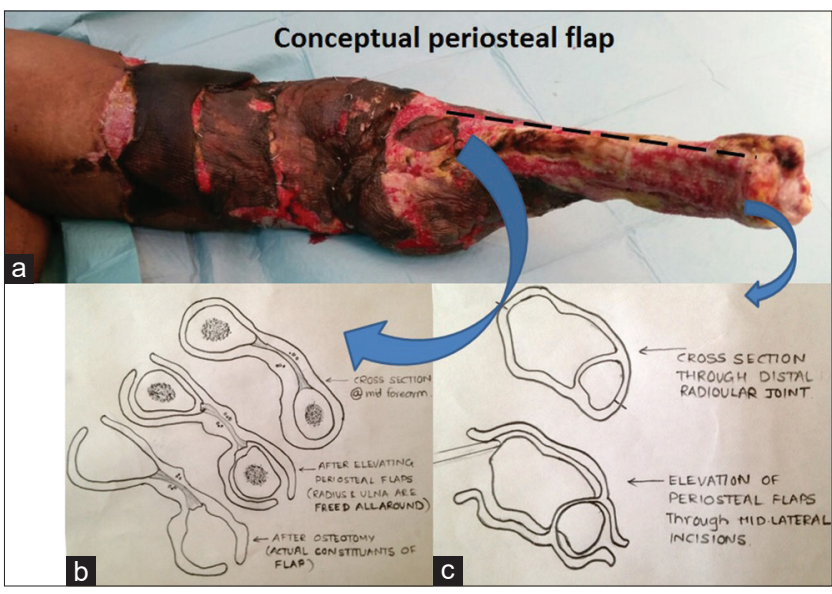

Figure 1: Conceptual local flap for coverage of the stump. (a) The condition of the limb 7 days following the initial debridement, when the patient was taken up for stump refashioning. (b) Arrangement of structures and elevation of flap at the distal radioulnar joint. (c) Represents structural arrangement at the mid forearm and diagrammatically shows the possible elevation of the flap. Circumferential subperiosteal dissection of the tissues and leaving attachment of these sleeves with the interosseous membrane intact to create a soft-tissue periosteal flap was attempted

- Proper inset was difficult with no available skin in the recipient forearm and arm

- Need of multiple delays (partly due to lack of proper inset)

- Difficulties in wound management with limb attached to the trunk

- Bulkiness of flap, needing secondary debulking procedures

- Long-term issues of an island of skin flap in the middle of skin grafted stumps such as persistent oedema and recurrent infections due to poor lymphatic drainage leading to possible difficulties in prosthetic fitting and use.

Use of soft-tissue periosteal flaps has been described both for the upper and lower limbs, but it is not very commonly used. ${ }^{[4,5]}$

Innovative use of available local tissue helps in reducing donor site morbidity and in turn would lead to quicker recovery and rehabilitation. This principle can be applied to similar defects in any amputated limb, especially as a salvage procedure when other options are not readily available.

\section{Financial support and sponsorship} Nil.

\section{Conflicts of interest}

There are no conflicts of interest.
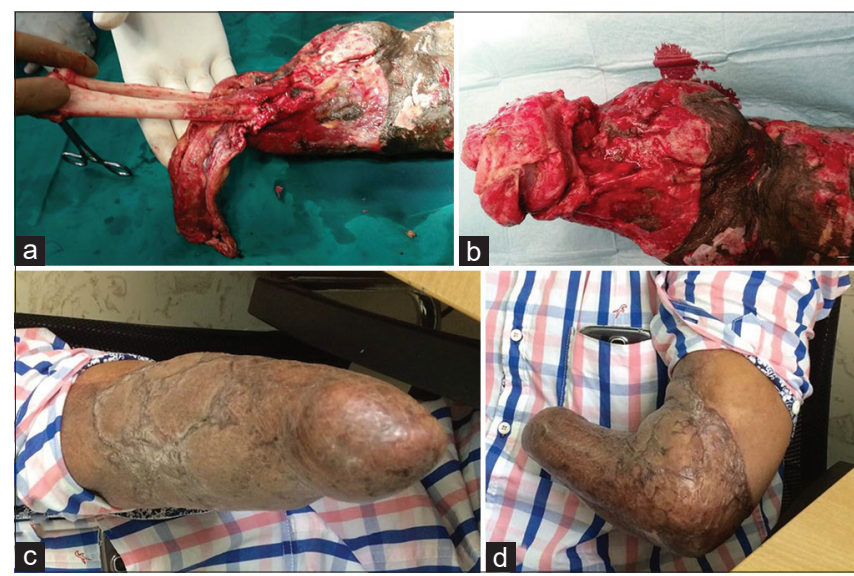

Figure 2: ( $a$ and $b$ ) Raising of the flap containing the soft tissue and periosteum. The flap thus raised had dimensions of $14 \mathrm{~cm} \times 6 \mathrm{~cm} \times 1.5 \mathrm{~cm}$. The bones were osteotomized at the predetermined site to retain adequate stump length, and the flap was wrapped around for cover. (c and d) The stump was covered adequately with the flap. Subsequently, the wound was skin grafted. The healed stump can be appreciated

Rahul Krishnarao Patil, Ahmed Osama Abdel Hamed, Srinivasan Venugopal, Mahil Cherian, Gopal Malhotra

Department of Hand and Microvascular Surgery and Khoula Hospital, Muscat, Sultanate of Oman

Address for correspondence: Dr. Rahul Krishnarao Patil, Department of Hand and Microvascular Surgery, Khoula Hospital, AI Wuttayya, PC 116, Muscat, Sultanate of Oman. E-mail: doctrahul@yahoo.co.in

\section{REFERENCES}

1. Latifi R, El-Hennawy H, El-Menyar A, Peralta R, Asim M, Consunji $\mathrm{R}$, et al. The therapeutic challenges of degloving soft-tissue injuries. J Emerg Trauma Shock 2014;7:228-32.

2. Koul AR, Patil RK, Nahar S. Unfavourable results in free tissue transfer. Indian J Plast Surg 2013;46:247-55.

3. Koul AR, Patil RK, Philip VK. Early use of microvascular free tissue transfer in the management of electrical injuries. Burns 2008;34:681-7.

4. Dailiana ZH, Malizos KN, Urbaniak JR. Vascularized periosteal flaps of distal forearm and hand. J Trauma 2005;58:76-82.

5. Mongon ML, Piva FA, Mistro Neto S, Carvalho JA, Belangero WD, Livani B. Cortical tibial osteoperiosteal flap technique to achieve bony bridge in transtibial amputation: Experience in nine adult patients. Strategies Trauma Limb Reconstr 2013;8:37-42.

This is an open access article distributed under the terms of the Creative Commons Attribution-NonCommercial-ShareAlike 3.0 License, which allows others to remix, tweak, and build upon the work non-commercially, as long as the author is credited and the new creations are licensed under the identical terms. 


\begin{tabular}{|l|l|}
\hline \multicolumn{2}{|c|}{ Access this article online } \\
\hline Quick Response Code: & Website: \\
\hline & www.ijps.org \\
\cline { 2 - 2 } & \\
\hline
\end{tabular}

How to cite this article: Patil RK, Hamed AO, Venugopal S, Cherian M, Malhotra G. Coverage of below elbow amputation stump with a soft-tissue periosteal flap. Indian J Plast Surg 2016;49:284-6. 